\title{
頭頸部癌に対する超選択的動注化学療法
}

\author{
中谷 宏章1) - 澤田 正一1) - 竹田 泰三1) - 中平 光彦1) \\ 熟頭 洋三1) - 福島 慶1) 山河 和博1) ・松本 州司1) \\ 竹内 $\quad$ 俊二2) $\cdot$ 長谷川賢作 ${ }^{3)} \cdot$ 北野 博也 ${ }^{3)}$
}

\section{Superselective Intraarterial Infusion Therapy for Head and Neck Carcinomas}

\author{
Hiroaki Nakatani, Shoichi Sawada, Taizo Takeda, Mitsuhiko Nakahira, \\ Yozo Washizu, Kei Fukushima, Kazuhiro Yamakawa and Shuji Matsumoto \\ (Kochi Medical School) \\ Shunji Takeuchi \\ (Kochi Prefectural Hata Kenmin Hospital)
}

Kensaku Hasegawa and Hiroya Kitano

(Tottori University School of Medicine)

\begin{abstract}
We report the results of superselective intraarterial cisplatin (CDDP) infusion therapy combined with irradiation for 23 patients, mainly advanced head and neck carcinoma. All patients received intraarterial CDDP infusions with intravenous sodium thiosulfate (STS) neutralization. CDDP infusion was performed by the Seldinger's technique in 16 patients and by the implanted intraarterial reservoir system in $7 \mathrm{pa}-$ tients. STS was also infused by the reservoir system implanted at the forearm in most patients.

An overall response was observed in 21 of the 23 (91.3\%) patients. Complete and partial responses were achieved in $16(69.6 \%)$ and $5(21.7 \%)$ patients, respectively. There were no patients with worse than grade III complications. We concluded that superselective intraarterial infusion therapy with a high dose of CDDP and STS was very effective for the management of advanced head and neck carcinomas and we recommend the implantable reservoir system for both CDDP and STS administration as an easy and low-invasive method.
\end{abstract}

Key words : superselective intraarterial infusion therapy, head and neck carcinoma, CDDP, implantable reservoir system

はじめに

頭頸部領域は日常生活を営む上で重要な諸臓器, 感覚 器が集中するのみならず, 整容的にも大切な部位である. このため, 頭頸部癌の治療に際しては常に治療後の機能 と整容性の温存を考慮しなければならない. しかしなが
ら, 進行癌においては放射線治療や化学療法による完治 はきわめて困難であり, 根治的治療を行らためには拡大 手術が必要であった。当科では, 現在主に進行癌を対象 として超選択的動注治療を試みている. 今回, 根治目的 に動注治療を行い, 治療が完遂できた症例において一次

1）高知大学聴平衡・嚥下機能統御学教室

2）高知県立幡多けんみん病院耳鼻咽喉科

3）鳥取大学耳鼻咽喉科・頭頸部外科学教室 
治療効果を検討したので報告する.

\section{対 象}

対象は平成 13 年 7 月以降に動注治療を行った頭頸部癌 新鮮例 23 例である（表 1). 性別は男性 16 例, 女性 7 例 で, 年齢は $44 \sim 85$ （平均 63.1）歳であった. 原発部位 は上顎癌が 6 例，中咽頭癌が 5 例，上咽頭，口腔，下咽 頭，喉頭癌がそれぞれ 3 例であった。 TNM 分類では T2 が 5 例，T 3 が 6 例，T 4 が 12 例，N0 が 12 例，N 1 が 4 例, N2 が 5 例, N 3 が 2 例で, M (+) 例はなかった. 病期分類では II, III 期がそれぞれ 4 例，IV 期が 15 例で, III 期以上の進行癌が 19 例（83\%）を占めていた。 このう ち, 症例 8，15，17，20 の 4 例は原発巣あるいは転移り ンパ節の進展が高度で手術不能と判断した症例であっ た.

\section{方法}

（1）動注方法

16 例にセルジンガー法， 7 例にリザーバー法を用いて 動注を行った.リザーバー留置に用いた血管は 4 例が浅 側頭動脈，3 例が顔面動脈で，カテーテルとこれに接続 したポートはともに皮下に埋め込んで使用した。

（2）使用薬剂

抗癌剤にはシスプラチン (CDDP) を用いた. CDDPの 1 回投与量は原則として $100 \mathrm{mg} / \mathrm{m}^{2}$ としたが, 75 歳以上 の高齢者のうち 3 例においては $80 \mathrm{mg} / \mathrm{m}^{2}$ の減量投与を 行った. 動注時の血管痛やれん縮予防のため, $7 \%$ 炭酸水 素ナトリウム $20 \mathrm{ml}$ と $2 \%$ リ゙カイン $2.5 \mathrm{ml}$ を加え, 動 注終了後には血管内皮細胞障害の予防のためリン酸ベタ メタゾンナトリウム $8 \mathrm{mg}$ も追加投与した。

CDDP 投与と同時に中心静脈から中和剤であるチ才硫 酸ナトリウム $(\mathrm{STS})$ を $12 \mathrm{~g} / \mathrm{m}^{2}$ で 45 分，さらに同量を 6

表 1 対象

\begin{tabular}{|c|c|c|c|c|c|c|c|c|c|c|c|c|}
\hline 症例 & 年齢・性 & 原発部位 & $\mathrm{T}$ & $\mathrm{N}$ & $\mathrm{M}$ & 病期 & 動注回数 & $\underset{(\mathrm{mg})}{\mathrm{CDDP}}$ & $\begin{array}{c}\text { 照射線量 } \\
\text { (Gy) }\end{array}$ & $\begin{array}{l}\text { 原発部の } \\
\text { 治療効果 }\end{array}$ & 手術治療 & 月数 - 経過 \\
\hline 1 & 53 - 男 & \multirow{3}{*}{ 上咽頭 } & 4 & 1 & 0 & IVA & 1 & 140 & 71 & $\mathrm{CR}$ & & $28 \cdot$ 肺転移 \\
\hline 2 & $54 \cdot$ 女 & & 4 & 0 & 0 & IVA & 1 & 150 & 70 & $\mathrm{CR}$ & & 27 - 非担癌 \\
\hline 3 & $52 \cdot$ 女 & & $2 \mathrm{~b}$ & 1 & 0 & IIB & 2 & 346 & 65 & CR & ND & 12 - 非担癌 \\
\hline 4 & 77 ·男 & \multirow{6}{*}{ 上顎 } & 3 & 0 & 0 & III & 6 & 960 & 50 & $\mathrm{PR}$ & 上頢部切 & 19 - 非担癌 \\
\hline 5 & 78 - 男 & & 3 & 0 & 0 & III & 5 & 690 & 50 & $\mathrm{CR}$ & 上顎部切 & 15 - 非担癌 \\
\hline 6 & $76 \cdot$ 女 & & 4 & 0 & 0 & IVA & 1 & 100 & 50 & PR & 上顎部切 & 13 - 非担癌 \\
\hline 7 & $51 \cdot$ 女 & & 4 & 0 & 0 & IVA & 5 & 850 & 50 & $\mathrm{NC}$ & & $9 \cdot$ 担癌 \\
\hline 8 & $50 \cdot$ 女 & & 4 & 0 & 0 & IVA & 6 & 910 & 50 & PR & 上顎部切 & 6 - 非担癌 \\
\hline 9 & $52 \cdot$ 女 & & 2 & 0 & 0 & II & 4 & 560 & 50 & $\mathrm{CR}$ & 上顎部切 & 5 - 非担癌 \\
\hline 10 & 65 - 男 & \multirow{3}{*}{ 口腔 } & 4 & 0 & 0 & IVA & 2 & 300 & 50 & $\mathrm{NC}$ & 拡大手術 + ND & 15 - 非担癌 \\
\hline 11 & 76 ·男 & & 2 & $2 \mathrm{c}$ & 0 & IVA & 4 & 600 & 60 & $\mathrm{CR}$ & & 9- 非担癌 \\
\hline 12 & 44 - 男 & & 4 & $2 \mathrm{c}$ & 0 & IVA & 5 & 975 & 60 & $\mathrm{CR}$ & ND & 8- 非担癌 \\
\hline 13 & 59 - 男 & \multirow{5}{*}{ 中咽頭 } & 4 & $2 \mathrm{~b}$ & 0 & IVA & 4 & 600 & 65 & $\mathrm{CR}$ & ND & 15 - 非担癌 \\
\hline 14 & 77 ·男 & & 4 & 1 & 0 & IVA & 5 & 500 & 65.4 & $\mathrm{CR}$ & & 11 - 非担癌 \\
\hline 15 & 55・男 & & 4 & $2 \mathrm{~b}$ & 0 & IVA & 5 & 860 & 65.4 & PR & & 10 - 担癌 \\
\hline 16 & 59 ·男 & & 4 & 0 & 0 & IVA & 7 & 1225 & 0 & PR & 舌根部切 & 6 - 非担癌 \\
\hline 17 & 48 - 男 & & 4 & 3 & 0 & IVB & 4 & 773 & 65.4 & $\mathrm{CR}$ & & 6. 非担癌 \\
\hline 18 & 85 ・男 & \multirow{3}{*}{ 下咽頭 } & 2 & 0 & 0 & II & 1 & 140 & 65.4 & CR & & 10 - 非担癌 \\
\hline 19 & 60 ・男 & & 3 & 0 & 0 & III & 1 & 160 & 60 & $\mathrm{CR}$ & & 8·非担癌 \\
\hline 20 & $66 \cdot$ 男 & & 3 & 3 & 0 & IVB & 1 & 130 & 65.4 & $\mathrm{CR}$ & & 6 - 非担癌 \\
\hline 21 & $58 \cdot$ 男 & \multirow{3}{*}{ 喉頭 } & 3 & $2 \mathrm{~b}$ & 0 & IVA & 4 & 640 & 61.2 & $\mathrm{CR}$ & ND & 11 - 非担癌 \\
\hline 22 & $80 \cdot$ 女 & & 2 & 0 & 0 & II & 1 & 120 & 63 & $\mathrm{CR}$ & & 11 - 非担癌 \\
\hline 23 & 76 ·男 & & 3 & 1 & 0 & III & 3 & 525 & 66 & $\mathrm{CR}$ & ND & 7 - 非担癌 \\
\hline
\end{tabular}




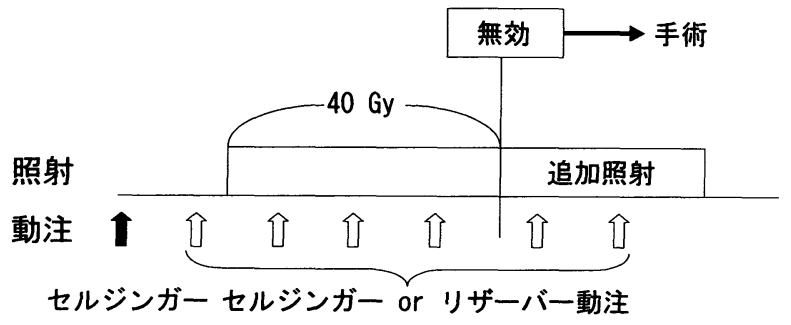

図 1 動注治療のプロトコール

時間追加投与した. STS も肘静脈から中心静脈内に埋め 込んだリザーバーを通じて投与した。

（3）治療プロトコール

当科で行っている治療のプロトコールを図 1 に示す. 照射と化学療法が主体となる上咽頭癌以外の例では, 治 療効果に応じて手術も検討する方針をとっている.まず, セルジンガー法で腫瘍の栄養動脈を確認し, その際に 1 回目の動注を行う. 2 回目以後は, リザーバー留置が可 能と考えられる症例ではリザーバー留置を行い，それが 困難な症例ではセルジンガー法で, 照射と平行し $1 \sim 2$ 週に 1 回の頻度で動注を行った. ただし, 上咽頭癌と原 発部位が比較的小さい喉頭 -下咽頭癌に対しては根治照 射の補助治療として 1,2 回の動注を施行した. 手術を行 うかどうかは $40 \mathrm{~Gy}$ 相当の照射が行われた時点で判断し, 無効な例では手術を行ったが, 上頡癌例は $\mathrm{CR}$ 例でも上 顎部分切除術を行った. 上顎部分切除術では機能的にも 整容的にも大きな問題を残さず，治療成績をより確実な ものにできると考えたからである.

\section{結 果}

動注回数は $1 \sim 7$ 回, CDDP の総投与量は $100 \sim$ $1225 \mathrm{mg}$, 併用した照射線量は 6 年前の下咽頭癌治療時 に根治照射を行っていた症例 16 を除き 50 〜 $71 \mathrm{~Gy}$ であっ た.

原発部位の肉眼的·画像的一次治療効果は CR が 16 例, CRに近いPRが5例で奏効率は $91.3 \%$ と良好であった. NC の 2 例はいずれも主たる栄養血管に十分な動注ができな かった症例であった。

その結果, 原発部位の手術を行ったのは最初から手術 を予定した上顎癌 5 例以外は 2 例のみで, 再建手術を要 する拡大手術を行ったのは NC であった煩粘膜癌 1 例の みであった. 残る 1 例は照射が併用できなかった症例 16 で, わずかに残存した腫瘍に対し舌根部の部分切除術を
施行した。 また，頸部郭清術も $\mathrm{N}(+) 11$ 例中 5 例のみ で, 頸動脈浸潤を伴う N3 の 2 例においても転移リンパ 節への動注が奏効し, 頸部郭清術は行わなかった。

動注治療時の主な有害事象は粘膜炎であり，ほぼ全例 に grade 2 の口内炎, 咽頭炎が出現したが, 照射を併用 しなかった症例 16 では生じなかった. grade 2 の悪化を みた検査は, 白血球減少が 4 例, 好中球減少が 1 例, ク レアチニン・クリアランスが 4 例で，いずれも一過性の 変化であり, grade 3 以上の異常を示した検查はなかっ た.

治療後の経過が短く最終的な予後は不明であるが， 23 例中 20 例が現在非担癌状態である. 担癌 3 例中, 症例 1 は治療後 1 年目に肺転移が確認されたが，現在まで原発 部位と頸部リンパ節の再発は認めていない. 症例 7 は初 回動注時に顎動脈の主たる栄養血管が閉塞した例で，他 の分枝からの動注が奏効しなかった. 当初より中頭蓋窩 内に進展した手術不能例であり, 腫瘍制御はできなかっ た. 症例 15 の扁桃癌例も原発部と転移リンパ節がともに 頸動脈に浸潤した手術不能例であり，治療終了時点では ほぼ CR に近い状態であったが, 治療終了後 7カ月目に 局所再発をきたした.

\section{症例}

症例 $9: 52$ 歳, 女性. 左上顎癌.

現病歴: 平成 15 年 2 月初旬より左鼻出血が出現. 近医 での CT にて上顎腫瘍を疑われ，他院総合病院を受診. 2 月 27 日, 同院での上顎洞試験開洞術にて中分化型扁平上 皮癌の診断. 3 月 10 日，治療目的にて当科転院. 術前の 画像診断では T2NOM0, stage II と診断された（図2a).

治療経過： 3 月 27 日, 左浅側頭動脈より顎動脈へリ ザーバー留置. 4 月 1 日, 中心静脈にリザーバーを留置 し, 4 月 2 日から CDDP 動注, 4 月 4 日から放射線照射 を開始した. 総照射線量は $50 \mathrm{~Gy}$, 動注回数は 4 回で, CDDP の総投与量は $560 \mathrm{mg}$ であった. その結果, 上顎洞 の腫瘍陰影は CR となったが (図 $2 \mathrm{~b}$ ), 組織学的な腫瘍 残存検索もかね称て 6 月 10 日拡大デンケル手術を施行. 肉眼上腫瘍所見は確認できず，永久病理標本でも腫瘍組 織は消失していた。

症例 $13: 59$ 歳, 男性. 左中咽頭前壁癌.

現病歴：平成 14 年 1 月下旬頃より嚥下痛, 3 月下旬頃 より左頸部腫瘤が出現し, 4 月 8 日当科受診. 初診時, 左 舌根部に腫瘍を認め, 同部の生検により扁平上皮癌の診 

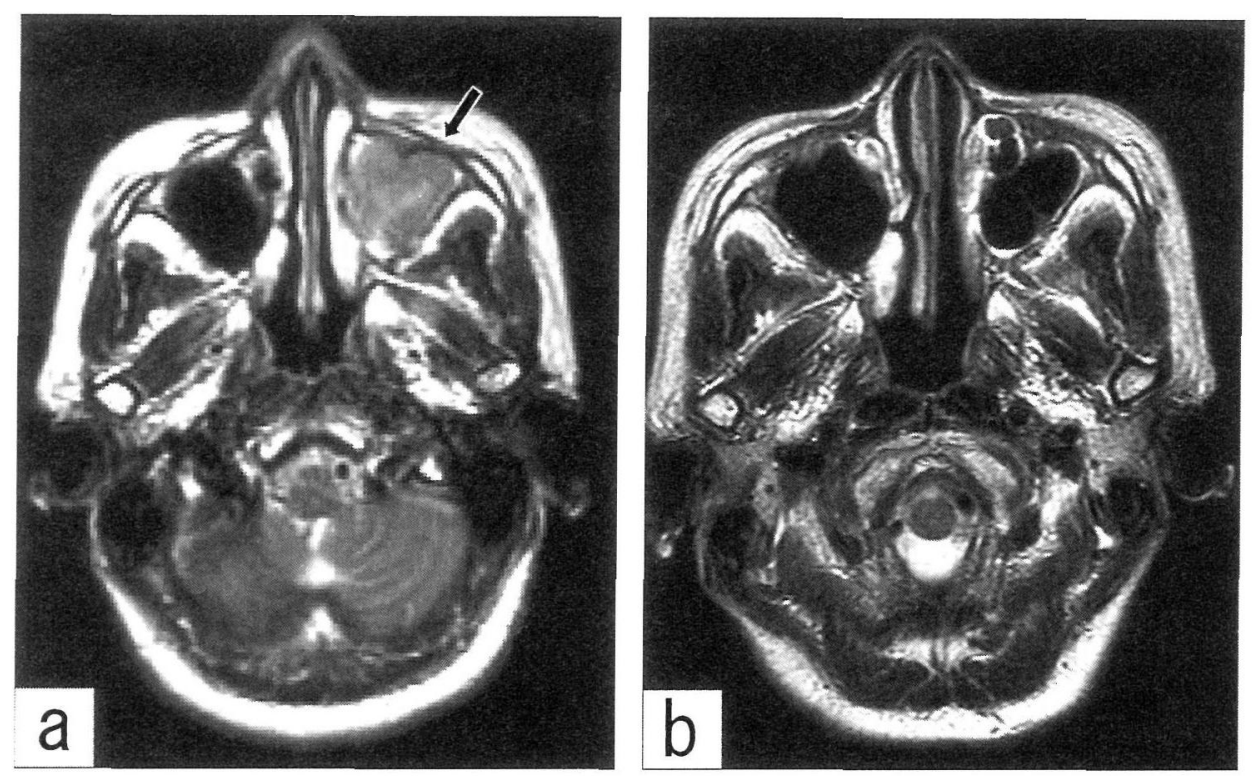

図 2 症例 9 の T2 強調 MRI 所見 ( $\mathrm{a}$ : 動注前, b : 動注後)

治療前上顎道内に充満していた腫瘍陰影（矢印）は治療後消失した。

断が得られた。左頸部には多発性のリンパ節腫脹を認め た。術前の画像診断では左舌根部に原発した腫瘍が舌深 部に深く浸潤しており，T4N2bM0， stage IVA と診断し た (図 $3 a, b)$.

治療経過：4月 23 日入院. 舌・喉頭全摘術を勧めるも 手術は希望されず，動注治療を行うこととした。 4 月 30 日, 中心静脈リザーバー留置後, セルジンガー法にて左 外頸動脈造影施行. 舌動脈上顔面動脈兮ら血流支配があ り, 両者一動注を行った。 その後放射線治療を開始し, 最終的に外照射 $65 \mathrm{~Gy}$, 動注 4 回, CDDP 総投与量 $600 \mathrm{mg}$ の治療を施行した。 $45 \mathrm{~Gy}$ 照射時点で頸部郭清術は行っ たが，原発部位は $\mathrm{CR}$ となり原発部の手術は行わなかっ た（図 $3 c ， d)$. 現在 15 力月を経過しているが，再発は認 めていない.

症例 $17: 48$ 歳, 男性. 右中咽頭側壁癌.

現病歷: 平成 14 年 12 月頃より右頸部腫瘤と咽頭痛出 現. 平成 15 年 2 月 18 日, 他院耳鼻咽喉科受診し, 右扁 桃部の生検にて高分化型扁平上皮癌の診断. 動注治療を 依頼され，2月 26 日当科受診。原発部位は右口蓋扁桃办 ら舌根, 軟口蓋, 内側翼突筋におよび, 両側の頸部リン パ節腫脹を認めたが, 特に右上内深頸リンパ節は $6 \mathrm{~cm}$ を 超え, 総頸動脈一の浸潤も認められた（T4N3M0, stage IVB, 図 $4 \mathrm{a}, \mathrm{b})$.
治療経過： 3 月 7 日入院. 総頸動脈に浸潤するリンパ 節のため手術による根治は困難と考光, 動注治療を予定. 3 月 18 日, 中心静脈りザーバー留置後, セルジンガー法 施行. 舌動脈より扁桃部への血流, 顔面動脈よりリンパ 節への血流を認め, 両者へ動注を施行. 以後もセルジン ガー法にて動注を行い, 計 4 回, CDDP 総投与量 $773 \mathrm{mg}$, 照射は $65.4 \mathrm{~Gy}$ 併用し, 原発部, リンパ節ともに CR と なった (図 $4 \mathrm{c}, \mathrm{d}$ ).

\section{考察}

頭頸部癌に対する超選択的動注治療の報告は1980年代 前半1) からみられるが，諸施設で行われるようになった のは 1990 年代以降2) 5) である. 特に, Robbins ら 2) が 進行癌に対しても高い治癒率が得られると報告して以 来, 本邦でも急速に広まりつつある。

本治療法の特徴は, 全身投与に比べはるかに高濃度の 抗癌剤を腫瘍内に取り込ませることができることにあ る. 頭頸部領域において抗癌剤の超選択的動注と経静脈 的投与で腫瘍組織に集まる抗癌剤の濃度を検討した報告 は涉猟し得ていないが，立山ら ${ }^{6)}$ は家鬼による腹部大動 脈からの選択的動注と静脈内投与で, 子宮と卵巣に集ま る抗癌剤の濃度差は 10 倍前後と報告している.また, 藤 内ら ${ }^{7)}$ は口腔癌における超選択的動注と選択的動注との 

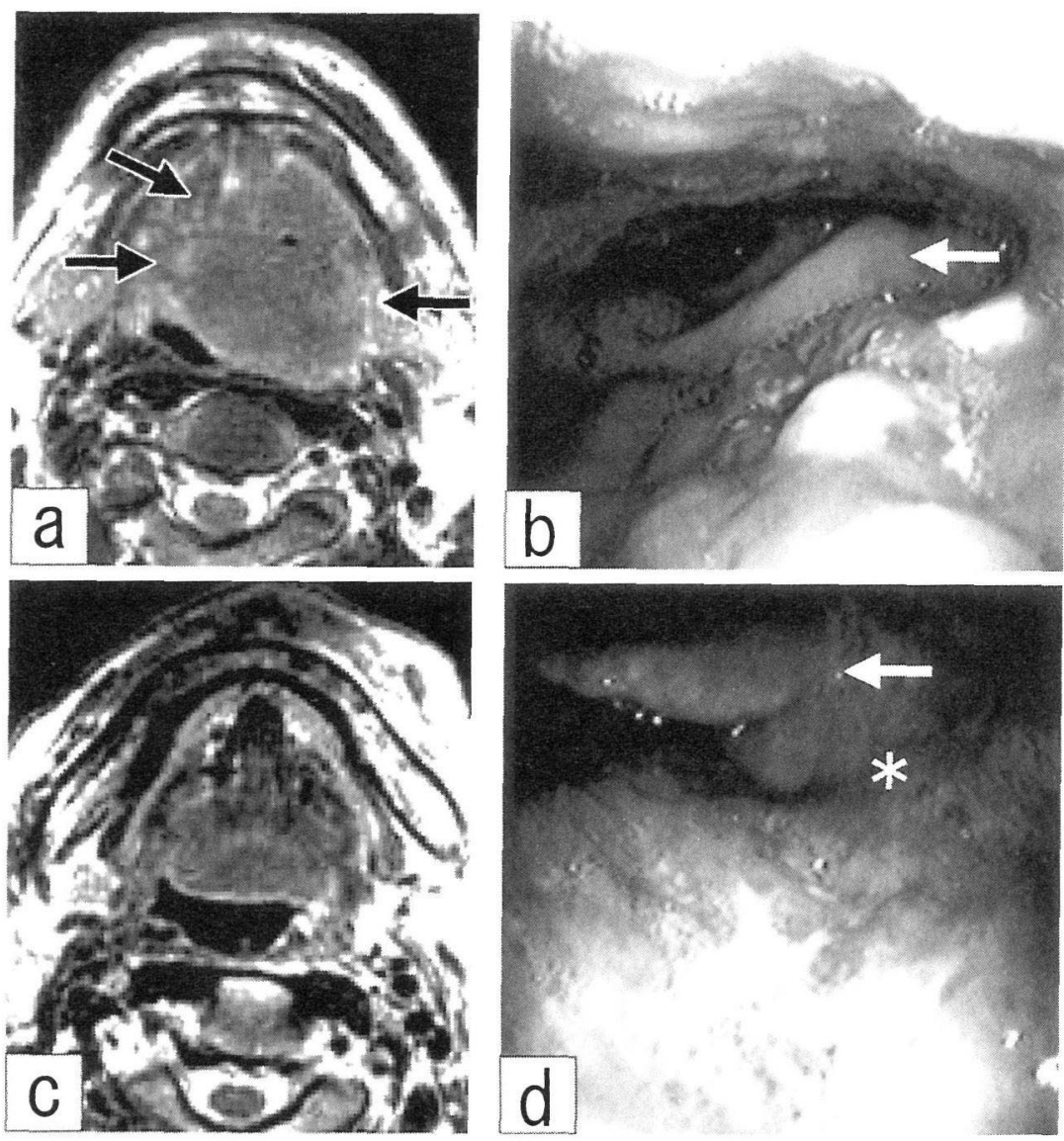

図 3 症例 13 の T2 強調 MRI 所見（a, b : 動注前, c, d : 動注後)

動注前, 腫瘍（黒矢印） は舌全体に広く浸潤し（a), 腫瘍の前方突出により喉頭蓋（白矢印）が圧排されている（b).動注後に は腫場陰影は消失し (c), 喉頭蓋谷（）も観察可能となった (d).

比較で, 超選択的動注の方が平均 2.2 倍腫瘍内に抗癌剤 が集まると報告している。こ秃らの結果からは超選択的 動注で取り込まれる抗癌剤の腫瘍内濃度は全身投与より も数十倍も高くなることが予想される.

使用されている抗癌剤は CDDP 以外に, カルボプラチ ン ${ }^{417)}$ ，ネダプラチン ${ }^{899)}$ ，ドセタキセル ${ }^{10)}$ など施設によ りさまざまであるが，われわれは中和剤 (STS) の使用 が特に有用な CDDP を用いている. CDDP ではSTS の使 用により全身の副作用が軽減できるため, 静注法よりも 1 回投与量が増量でき, 投与間隔も短縮できる。このた め, 静注法に比較してきわめて高濃度の CDDP 長期間 腫瘍内に蓄積することができる。 CDDP は細胞周期非特 異性抗癌剂であり, 濃度依存性に殺細胞効果が高まる抗 癌剤であるため, STS 用いた大量の CDDP 超選択的動 注治療はCDDPの薬理効果からも理にかなった方法と考
えられる.

しかし超選択的動注治療にもいくつかの問題点があ り11) 14)，なかでも沉用されているセルジンガー法に伴 ら脳梗塞はきわめて重篤な合併症として注意を要する。 諸家の報告11) 14) では脳梗塞の頻度は $1 \%$ 前後とされて おり, まれな合併症とはいえない.さらに，煩雑な操作， 治療に要する時間, 治療後の安静処置, 放射線科医に依 頼して血管造影室で行う必要があることなどを考える と, セルジンガー法による治療は簡単に行えるものでは なく, 患者にとっても楽な治療とはいいがたい.

このような理由から，われわれは複数回の動注治療が 必要とされる症例には積極的にリザーバー法を行うこと にしている，リザーバー法は腫瘍の栄養血管以外の外頸 動脈分枝からカテーテルを挡入する方法であるが，われ われは動注用カテーテルと中和剤投与用の中心静脈カ 

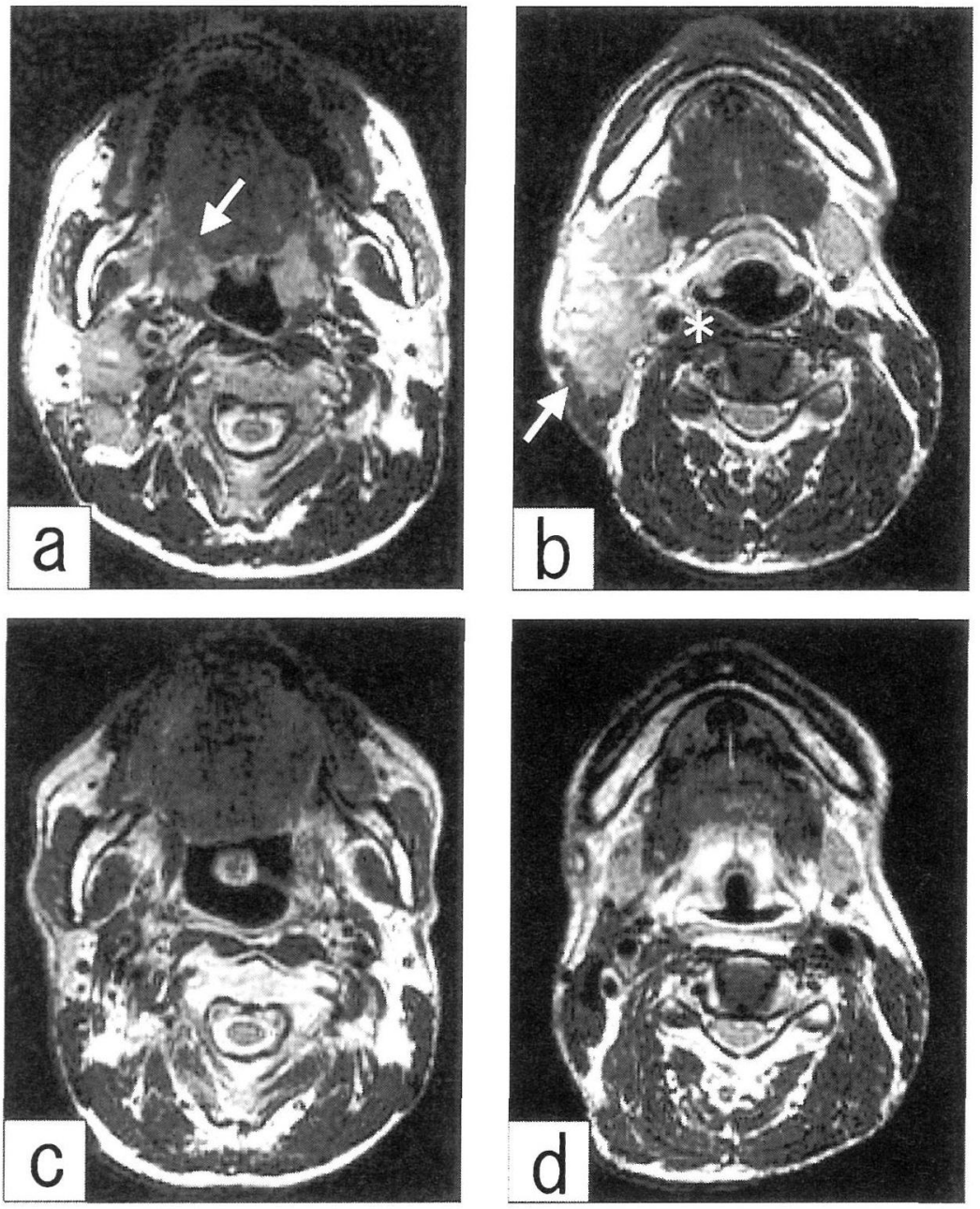

図 4 症例 17 の $\mathrm{T} 2$ 強調 MRI 所見（a，b：動注前，c， d : 動注後）

右口蓋扁桃から原発した腫瘍（矢印）は舌根，内側翼突筋に浸潤し，多発性のリンパ節転移も認められる（a）。転移リンパ節 （矢印）が総頸動脈（）に浸潤している（b)。動注後（c，d）は，原発巣も転移リンパ節もCRとなった。

テーテルをともに皮下に留置, 固定して動注を行ってい る。両者を併用すると, 以後の動注操作は 2 つの皮下ポー 卜に注射針を刺すだけでよく，通常の点滴治療と同程度 の簡便性, 低侵襲性で動注治療が行える。しかも脳梗塞 の危険性がない.今回の対象では 23 例に計 78 回の動注 を行ったが，らち 31 回（39.7\%）はリザーバー経由での 動注であった。脳梗塞は絶対に回避すべき合併症である ので，今後もリザーバー法を積極的に行う予定である.

今回検討を行った 23 例の治療成績はきわめて良好で あった。原発部位の CT，MRI を用いた画像的治療効果 は CR が 16 例 (69.6\%), ほぼ CR に近い PR が 5 例 (21.7 \%)であった。 全例に組織学的評価は行っていないが,
CR 16 例中, 手術および生検を行った 11 例では全例が変 性した癌細胞を認めるか，癌細胞のない結果であった。 また，PR 5 例においても，上顎部分切除術を行った症例 4 上 6 では変性した癌細胞をわずかに認めたのみで組織 学的には CR と考光られ, 生検を行った症例 15 の中咽頭 組織からは癌細胞は検出されなかった。残る 2 例には摘 出組織から変性のない癌細胞がわずかに認められたが, 症例 8 は非常に局所進展の高度な上顎癌例，また症例 16 は放射線照射のできなかった中咽頭癌例であり，これら 5 例においても超選択的動注治療の有効性は明らかで あった。

NC 2 例のうち症例 7 の上顎癌例は初回動注時に顎動脈 
の主たる栄養血管を血栓にて閉塞してしまった．他の小 分枝より血流がみられたので動注を行ったが，十分な治 療効果は得られなかった. また, 症例 10 の煩粘膜癌例は 副咽頭間隙に深く進展した例で，動注を行った顔面動脈 以外からの血流支配も疑われた. すなわち, NC 2 例は適 切な動注治療が行えなかったことが, 治療が奏効しな かった要因の一つと考えられた。

最終的な治療成績についてはまだ経過観察期間が短 く, 結論をだせる段階にはない. しかしながら, 現在の ところ担癌例はわずかに 3 例であり, うち 2 例は治療前 より手術不可能な進行癌例, 残る 1 例は原発部位には 2 年以上を経て再発のみられない肺転移例である. 対象の 多くが進行癌症例で, 広範な切除手術を併用していない ことを考慮すると非常に優れた治療成績であると考えら れた.

最後に, 現在われわれが考えている超選択的動注治療 の適応症例は，(1) 再建手術を必要とする進行癌例や (2) 総・内頸動脈浸潤などの手術不能例で，かつ（3）病変が 外頸動脈系から血流支配を受けている症例，(4) 抗癌剂 の使用が可能な症例，（5）過去に脳梗塞の既往がなく, 頸動脈の動脈硬化病変があまりないと考えられる症例で ある，また，T2 までの症例においても，(6) 放射線単独 では根治が難しく, 拡大手術の可能性が高い症例も適応 としてよいと考えている，ただし，本治療は放射線単独 治療よりも局所の浮腫や壊死病変をきたす危険性が高 い.このため, 現段階では根治には十分量の照射と動注 が必要であるが，ひとたび浮腫や壊死を生じると重篤な 病態をきたす可能性のある進行した喉頭癌や下咽頭癌に おいては積極的には行っていない，また，根治照射と高 濃度の抗癌剤投与を受けた部位のサルベージ手術は剥離 操作や切除範囲の決定が難しくなり, 術後合併症の危険 性も高くなることが予想される，本治療を行う際には， このような点も考慮し，適応例の決定には慎重な対応が 必要と考える.

\section{まとめ}

今回, 頭頸部癌 23 例に CDDP を用いた超選択的動注 治療を施行した. 重篤な合併症をきたした症例はなく, CR 率 $69.6 \%$ ，奏効率 $91.3 \%$ と非常に良好な結果であっ た. また，皮下埋め込み式りザーバーを用いた方法は動 注操作を低侵襲かつ簢便に行うために非常に有用であっ た. 本法は頭頸部進行癌患者の QOL を高めるために非
常に有用な治療法と考えられる.

なお, 本論文の要旨は, 第 65 回耳鼻咽喉科臨床学会 (平成 15 年 7 月 4 日, 京都市) においてポスター発表した。

\section{参考文献}

1) Sessions RB, Lehane DE, Smith RJH, et al. : Intra-arterial cisplatin treatment of adenoid cystic carcinoma. Arch Otolaryngol $108: 221 \sim 224,1982$.

2) Robbins KT, Storniolo AM, Kerber C, et al. : Rapid superselective high-dose cisplatin infusion for advanced head and neck malignancies. Head Neck $14: 364 \sim 371,1992$.

3) Korogi $Y$, Hirai $T$, Nishimura, et al. : Superselective intraarterial infusion of cisplatin for squamous cell carcinoma of the mouth; preliminary clinical experience. AJR Am J Roentgenol $165: 1269 \sim 1272,1995$.

4）不破信和, 伊藤善之, 加藤恵理子, 他：頭頸部局所進行癌 に対する CBDCA 超選択的持続動注療法併用放射線治療. 頭頸部腫瘍 $22: 139 \sim 143,1996$.

5）横山純吉，志賀清人，西條 茂，他：二経路投与法による 超選択的動注療法. 頭頸部腫瘍 $24: 335 \sim 343,1998$.

6）立山一郎, 森崇英国, 富永敏朗, 他：CDDP 動注法と静注 法における Platin の性器組織内濃度および血中・尿中動態 の比較研究. J Jpn Soc Cancer Ther $22: 614 \sim 620 ， 1987$.

7）藤内 祝, 不破信和, 林 康司, 他：口腔癌における浅側 頭動脈より超選択的動注法を用いた化学療法の検討一組織 内濃度と病理的効果一. 頭頸部腫瘍 $25: 59 \sim 64,1999$.

8）岩崎昭憲, 外山芳弘, 斎藤仁美, 他：口腔癌に対する Nedaplatin を用いたターグティング動注療法の検討. 癌と化学療 法 $28: 1027 \sim 1033,2001$.

9）山下佳雄, 後藤昌昭, 香月 武: 口腔癌に対する Nedaplatin を用いた超選択的動注療法と放射線照射併用療法の検討. Jpn J Cancer Chemother 29 : $905 \sim 909 ， 2002$.

10）秋定 健, 原田 保, 竹本环司，他：Docetaxel の超選択的 動注が有効であった進行下咽頭癌の1例. 癌と化学療法 29: $323 \sim 328,2002$.

11）志賀清人，舘田 勝，横山純吉，他：頭頸部扁平上皮癌に 対する超選択的動注療法の成績と合併症の検討．頭頸部腫 瘍 $27: 9 \sim 16,2001$.

12）石田晃弘, 小池修治, 那須 隆, 他：超選択的二経路動注 化学療法における副作用と合併症についての検討. 頭頸部 腫瘍 $28: 243 \sim 247,2002$.

13）野本幸男, 鹿野真人, 渡邊 睦, 他：頭頸部癌に対する超 選択的 CDDP 動注療法の有害事象の検討. 頭頸部腫瘍 28 : $248 \sim 252,2002$.

14) Robbins KT, Kumar P, Wong FSH, et al. : Targeted chemoradiation for advanced head and neck cancer; analysis of 213 patients. Head Neck $22: 687 \sim 693,2000$.

原稿受付：平成15年11月28日

原稿採択 : 平成15年12月10日 別刷請求先：中谷宏章

干783-8505 南国市岡豊町小蓮 高知大学医学部聴平衡・噁下機能統御学教室 